\title{
Phytochemical Analysis and Evaluation of Anti-angiogenic and Anti- proliferative Activities of the Leaves of Elaeagnus angustifolia L. Grown in Jordan
}

\author{
Aman A Ishaqat ${ }^{1,2^{\star}}$, Rana Abu-Dahab ${ }^{1}$, Hana M Hammad ${ }^{3}$, Malek Al-Zihlif ${ }^{4}$, Ismail F Abaza ${ }^{1}$, Zeyad D Nassar ${ }^{5}$ and Fatma U Afifi ${ }^{1}$ \\ ${ }^{1}$ School of Pharmacy, The University of Jordan, Queen Rania Al-Abdullah Street, Amman 11942, Jordan \\ ${ }^{2}$ Faculty of Pharmacy, Al-Zaytoonah University of Jordan, Queen Alia International Airport Street, Amman 11733, Jordan \\ ${ }^{3}$ School of Science, The University of Jordan, Queen Rania Al-Abdullah Street, Amman 11942, Jordan \\ ${ }^{4}$ School of Medicine, The University of Jordan, Queen Rania Al-Abdullah Street, Amman 11942, Jordan \\ ${ }^{5}$ School of Pharmacy, University of Queensland, 20 Cornwall Street, Woolloongabba, QLD 4102, Australia
}

"Corresponding author: Ishaqat AA, School of Pharmacy, The University of Jordan, Queen Rania Al-Abdullah Street, Amman 11942, Jordan, Tel: +962796448325; Email: aman.ishaqat@gmail.com

Received: March 14, 2018; Accepted: March 29, 2018; Published: April 06, 2018

Copyright: ( 2018 Ishaqat AA, et al. This is an open-access article distributed under the terms of the Creative Commons Attribution License, which permits unrestricted use, distribution, and reproduction in any medium, provided the original author and source are credited.

\begin{abstract}
Elaeagnus angustifolia $L$. has a long history of use in ethnopharmacology. Only few studies examined the potential activities of the leaves. Furthermore, the leaves' chemical composition was not fully investigated. In this study, the chemical composition of $E$. angustifolia leaves extract was analysed and major compounds were isolated and identified. Extract obtained by maceration was further extracted with solvents differing in their polarity then submitted to open column chromatography, followed by isolation of major compounds. They were analysed using UV-Vis and/or NMR. One terpene ( $\beta$-sitosterol) and four flavonoids (chrysin-7-glucoside, rutin, luteolin and kaempferol) were isolated and identified. For the biological activities, leaves were extracted using ethanol, ethyl acetate, chloroform and water. Anti-angiogenic activity was studied by rat aortic ring assay. Anti-proliferative activity was studied against MCF-7 and T-47D breast cancer cell lines. Ethyl acetate extract was found cytotoxic against T-47D breast cancer cell line $\left(\mathrm{IC}_{50}=23.05 \mu \mathrm{g} / \mathrm{mL}\right)$. Potent anti-angiogenic activity of ethanol- $\left(\mathrm{IC}_{50}=3.039 \mu \mathrm{g} / \mathrm{mL}\right)$, ethyl acetate- $\left(\mathrm{IC}_{50}=6.289 \mu \mathrm{g} / \mathrm{mL}\right)$ and water-extract $\left(\mathrm{IC}_{50}=7.153 \mu \mathrm{g} / \mathrm{mL}\right)$ was reported for the first time.
\end{abstract}

Keywords: Elaeagnus angustifolia; Anti-angiogenesis; Breast cancer; Flavonoids; Terpenes; Jordan

\section{Introduction}

Plant kingdom is a well-known source of useful drugs in many therapeutic fields. The plant investigated in the current study is Elaeagnus angustifolia L., from the Elaeagnaceae family. E. angustifolia is a small tree or shrub that grows to 5-7 meters in height. It is native to western and central Asia, Afghanistan, from southern Russia and Kazakhstan to Turkey and Iran. It was also introduced to the United States and Canada [1].

E. angustifolia has a long history of use in ethnopharmacology [2]. It is used as an analgesic for rheumatoid arthritis in Iran. Fruits and flowers are also used in the treatment of nausea, vomiting, asthma and jaundice $[3,4]$. In addition, oil from the seeds is used with syrup as a paste to treat bronchial conditions [3]. In traditional Chinese medicine, the leaf extract is used in the treatment of asthma and chronic bronchitis, in addition to its anti-tussive properties [5]. In Turkey, the fruits of E. angustifolia are used as tonic and as antipyretic, as well as to treat kidney inflammation, kidney stones and diarrhoea [6]. Researchers have investigated the bioactivity of different parts of E. angustifolia, grown in different locations of Turkey and Iran. The seeds exerted muscle relaxant [7] and anti-nociceptive activity $[8,9]$ in mice. Aqueous extract was found to have antiinflammatory and pain reducing ability, probably by inhibiting cyclooxygenase type 1 and 2 [10]. It was also found to be effective in treatment of knee osteoarthritis [11]. The fruit aqueous extract was found to accelerate cutaneous wound healing [12]. Researchers also discovered that using film containing $E$. angustifolia helped reduce gag reflex; a problem that commonly occurs during dental procedures [13].

Cancer remains to be one of the leading causes of death worldwide $[14,15]$. Anti-proliferative activity was investigated in addition to the anti-angiogenic activity as tools for determining potential anti-cancer activity of the extract. Angiogenesis is the formation of new blood vessels from existing vessels [16]. Two types of angiogenesis can be distinguished; sprouting angiogenesis and splitting angiogenesis. Sprouting angiogenesis was the first type discovered in tumor growth by Judah Folkman in $1971[17,18]$. Angiogenesis is a hallmark of cancer which is involved in two main aspects. First, without angiogenesis a tumor cannot grow beyond a limited size, usually 1-2 $\mathrm{mm}^{3}$ [19]. Formation of new blood vessels provides adequate supply of oxygen and nutrients to the rapidly growing cells. Furthermore, the new vessels serve as waste pathway for biological end products of the cancerous cells. Tumor cells trigger an "angiogenic switch" in their microenvironment [20]. This is achieved by upregulating the levels of their secretion of pro-angiogenic factors. At the same time, angiogenesis endogenous inhibitors are down regulated [21].

This study was designed to investigate and characterize the chemical composition of the leaves of $E$. angustifolia grown in Jordan and to study its potential anti-proliferative and anti-angiogenic activities. 
Citation: Ishaqat AA, Abu-Dahab R, Hammad HM, Al-Zihlif M, Abaza IF, et al. (2018) Phytochemical Analysis and Evaluation of Anti-angiogenic and Anti-proliferative Activities of the Leaves of Elaeagnus angustifolia L. Grown in Jordan. Nat Prod Chem Res 6: 319. doi: $10.4172 / 2329-6836.1000319$

Page 2 of 6

\section{Materials and Methods}

\section{Chemicals}

Chemicals were obtained from Sigma (Dorset, UK), unless otherwise stated.

\section{Plant material and phytochemical analysis}

Elaeagnus angustifolia $L$. leaves were collected from trees growing in The University of Jordan in late spring/ early summer time of 2014. Plant was taxonomically identified and authenticated by Prof. Barakat Abu Irmaileh, Faculty of Agriculture, The University of Jordan. Voucher specimens (ELEA-1FMJ) were deposited in the Department of Pharmaceutical Sciences, Faculty of Pharmacy, The University of Jordan. Fresh plant samples were air dried at room temperature and coarsely powdered. Maceration in $70 \%$ ethanol until exhaustion followed by solvent evaporation using rotary evaporator (Heidolph, Germany) at $40^{\circ} \mathrm{C}$ until a syrupy residue remained. All evaporated extracts were combined and dissolved in distilled water/ methanol mixture (1:1). It was washed with petroleum ether then submitted to exhaustive liquid-liquid extraction using chloroform and n-butanol. Each fraction was evaporated to dryness and crude extracts were obtained. Extracts were submitted to column chromatography (CC). Silica gel with $0.035-0.07 \mathrm{~mm}$ in diameter and pore diameter ca $6 \mathrm{~nm}$ (Acris Organics, USA) was used as stationary phase. Development of column was achieved with chloroform-methanol (100:0 to 0:100). Fractions of $100 \mathrm{~mL}$ were collected and evaporated to dryness using rotary evaporator. Fractions were evaluated by pre-coated TLC sheets (ALUGRAM S1L G/UV 254, Machery-Nagel GmbH and Co., Germany). Fractions that are similar in composition were collected together. Fractions that show great complexity in their composition were submitted to smaller sub-columns for further fractionation. Preparative TLC was used to isolate major compounds. To identify compounds, several methods were employed, in addition to $R_{f}$ value and color reaction comparison with reference substances. The absorbance spectra of the isolated compounds (UV-Vis) were determined and compared to reference compounds library and literature data. For structure determination, ${ }^{1} \mathrm{H}$ NMR, ${ }^{13} \mathrm{C}$ NMR and dept 90 and dept 135 NMR were used.

\section{Extracts preparation for biological activities screening}

Ten grams of powdered leaves were weighed and gently boiled with $100 \mathrm{~mL}$ of the solvent for 10 minutes. Four different solvents were used; water, ethanol, chloroform and ethyl acetate. Extracts were covered and left overnight. Filtration followed by evaporation until dryness was performed the next day. To obtain stock solution, each 0.1 g plant extract was dissolved in $10 \mathrm{~mL}$ DMSO. Appropriate dilutions were prepared for each assay.

\section{Cell lines and cell culture}

All procedures followed in the tissue culture to screen for antiproliferative activity were conducted according to standard protocols established and verified by research group of the same laboratory [22]. All cell lines under study were purchased from the American Type Culture Collection (ATCC). Two breast cancer cell lines, MCF-7 and $\mathrm{T}-47 \mathrm{D}$, and one normal fibroblasts cell line were investigated. They were all cultured in RPMI medium (PAA Laboratories GmbH, Austria) supplemented with of $10 \%$ fetal bovine serum (Biochrome, Germany), $1 \%$ of $2 \mathrm{mM}$ L-glutamine (Biochrome, Germany), $50 \mathrm{IU} / \mathrm{mL}$ penicillin and $50 \mu \mathrm{g} / \mathrm{mL}$ streptomycin (Thermo Scientific, USA). All cells were maintained at $37^{\circ} \mathrm{C}, 5 \% \mathrm{CO}_{2}$ in a humidified incubator (Binder, Germany).

\section{In-vitro anti-proliferative and cytotoxicity assay}

The four extracts prepared as described earlier were tested for their antiproliferative activity against two breast cancer cell lines; MCF-7 and T-47D. MCF-7 and T-47D cells were seeded at the density of 5,000 cells/ well and allowed to attach overnight. Plant extracts were screened on the following concentrations; $100,50,25,12.5,5,2.5,0.5$, 0.25 and $0.05 \mu \mathrm{g} / \mathrm{mL}$. Each concentration was added in triplicate. Control wells were filled with equal volume of $1 \%$ DMSO (MerckSchuchardt, Germany). Doxorubicin s used as standard reference anticancer drug. After 72 hours, the cell viability was assessed using sulforhodamine B (SRB) assay. In addition, the extracts were tested for their cytotoxicity against normal human fibroblasts cell line. The same protocol was used, except that the cell density was 20,000 cells/ well and incubated for 7 days with regular media replacement.

\section{SRB assay}

Cell monolayers were fixed with $200 \mu \mathrm{L}$ of $10 \% \mathrm{w} / \mathrm{v}$ trichloroacetic acid (Reidel-de Haën, Germany) and incubated at $4^{\circ} \mathrm{C}$ for 60 minutes. Then plates were washed with cold water four times. Excess water was drained and plates were left to dry at room temperature. Then, $50 \mu \mathrm{L}$ of SRB stain (Sigma Aldrich, USA) was added to each well and left for additional 30 minutes. The dye will bind to proteins in the living cells. Next, excess dye was removed by washing several times with $1 \% \mathrm{v} / \mathrm{v}$ acetic acid. The protein-bound dye was dissolved in $100 \mu \mathrm{L}$ of $10 \mathrm{mM}$ Tris base (Promega Corporation, USA) solution $(\mathrm{pH}=10.5)$. Plates were shaken gently for 15 minutes then absorbance of each well was read using ELISA plate reader (BioTek Instruments, USA) at $570 \mathrm{~nm}$. The viability of the cells was expressed as the mean percentage of viable cells compared with control DMSO treated cells [22].

\section{Anti-angiogenic activity}

The procedure of rat aortic ring assay was carried out according to the rules of the Animal Ethics Committee of The University of Jordan. Male Sprague Dawley rats weighing 200-250 grams were provided from the animal house of the Department of Biological Sciences, Faculty of Science, The University of Jordan. The rats were anesthetized gently with diethyl ether (Gainland Chemical Company, UK) and the thoracic aortae were excised, rinsed with phosphate buffer saline (Biowest, France), cleaned from the fibroadipose tissue and cross sectioned into thin rings of $1 \mathrm{~mm}$ thickness under the microscope. Each ring was embedded in $25 \mu \mathrm{L}$ low growth factors (LGF) Matrige ${ }^{\mathrm{Tw}}$ (Corning, USA) in 48 -well plate. The plate was incubated at $37^{\circ} \mathrm{C}$ for 30 minutes to allow for proper solidification. Then a volume of $250 \mu \mathrm{L}$ of the desired concentration of the extract was applied in triplicate. The plate was then incubated at $37^{\circ} \mathrm{C}$. On day 4 , the media was aspired and fresh media containing extracts was added. On day 6 , the rings were photographed under an inverted light microscope (Nikon, Japan). The angiogenic response was determined by measuring the length of blood vessels outgrowth from the primary ring explants on day 6 using ImageJ software (National Institute of Health, Bethesda, MD). The growth distance of at least 35 structures per ring selected at regular intervals around the ring was measured. Arbitrary units were used to express the actual length of the vessels. The following formula was used to calculate the inhibition of blood vessels formation: 
Citation: Ishaqat AA, Abu-Dahab R, Hammad HM, Al-Zihlif M, Abaza IF, et al. (2018) Phytochemical Analysis and Evaluation of Anti-angiogenic and Anti-proliferative Activities of the Leaves of Elaeagnus angustifolia L. Grown in Jordan. Nat Prod Chem Res 6: 319. doi: $10.4172 / 2329-6836.1000319$

Page 3 of 6

Blood vessels inhibition $=(1-(\mathrm{A} / \mathrm{A}))^{\star} 100$, where:

$A^{0}$ : distance of blood vessels growth in treated rings in arbitrary units.

\section{A: distance of blood vessels growth in control in arbitrary units.}

A preliminary screening was done with the concentrations of 150 , 100 and $50 \mu \mathrm{g} / \mathrm{mL}$ of each of the four extracts. The active extracts were then applied in serial dilution of different concentrations as follows: 25 , 12.5, 6.25 and $3.125 \mu \mathrm{g} / \mathrm{mL}$. For the negative control, DMSO was used at a concentration of $1 \%$. Suramin was used as positive anti-angiogenic control. Statistical analysis was done using Oneway analysis of variance (ANOVA) with Dunnett's test using GraphPad Prism 6 was done. pvlaue $<0.05$ was considered significant and NS indicates nonsignificance.

\section{Results and Discussion}

\section{Phytochemical analysis}

Two chemical classes of secondary metabolites were identified; terpenes and flavonoids. Terpenes were identified in all fractions obtained from the chloroform column and in early fractions eluting from n-butanol- and ethanol-columns. Preliminary identification of $\beta$ sitosterol was achieved by TLC by comparison of $\mathrm{R}_{\mathrm{f}}$ value and based on colour reactions using the reference using analytical TLC. The compound was then isolated and identified as $\beta$-sitosterol by spectral analysis using ${ }^{1} \mathrm{H},{ }^{13} \mathrm{C}$ and dept NMR. ${ }^{1} \mathrm{H}$ NMR spectrum showed six methyl groups: $\mathrm{C}_{29}(\delta=0.694,3 \mathrm{H}, \mathrm{s}), \mathrm{C}_{24}, \mathrm{C}_{26}$ and $\mathrm{C}_{27}(\delta=0.778-0.878$, $9 \mathrm{H}, \mathrm{m}), \mathrm{C}_{19}(\delta=0.974,3 \mathrm{H}, \mathrm{d})$ and $\mathrm{C}_{28}(\delta=1.022,3 \mathrm{H}, \mathrm{s})$. Protons at $\mathrm{C}_{3}$ $(\delta=3.505), C_{4}(\delta=2.285), C_{6}(\delta=5.371)$ and $C_{7}(\delta=2.011)$ were clearly identified. However, the rest of protons appeared as multiples in the region $\delta=1.084$ to 1.879 . The ${ }^{13} \mathrm{C}$ NMR showed 29 carbons. Dept 135 and dept 90 indicated the presence of $3 \mathrm{C}, 9 \mathrm{CH}, 11 \mathrm{CH}_{2}$ and $6 \mathrm{CH}_{3}$.

The second group of secondary metabolites identified was flavonoids. The presence of flavonoids kaempferol, rutin and luteolin was established initially by comparison with standard references on TLC and further confirmed by measuring their UV-Vis spectra using different shifting reagents; $\mathrm{NaOMe}, \mathrm{AlCl}_{3}, \mathrm{AlCl}_{3}+\mathrm{HCl}, \mathrm{NaOAc}$ and $\mathrm{H}_{3} \mathrm{BO}_{4}$ with the samples isolated by preparative TLC. Comparison of the obtained data for these flavonoids from E. angustifolia with the spectra of reference substances confirmed their identity [23]. Data obtained through UV-Vis analysis is listed in Table 1.

\begin{tabular}{|c|c|c|c|c|c|}
\hline \multicolumn{6}{|c|}{ UV-Vis Spectra ( $($ max) } \\
\hline $\mathrm{MeOH}$ & $\mathrm{MeOH+NAOMe}$ & $\mathrm{MeOH}+\mathrm{AlCl}_{3}$ & $\mathrm{MeOH}+\mathrm{AlCl}_{3}+\mathrm{HCl}$ & $\mathrm{MeOH}+\mathrm{NaOAc}$ & $\mathrm{MeOH}+\mathrm{NaOAC}+\mathrm{H}_{3} \mathrm{BO}_{4}$ \\
\hline Band I: 368 & Band I: 417 & Band I: 350,426 & Band I: 350,426 & Band I: 382 & Band I: 372 \\
\hline Band II: 266 & Band II: 269 & Band II: 270 & Band II: 270 & Band II: 274 & Band II:272 \\
\hline Band I: 362 & Band I: 415 & Band I: 440 & Band I: 402 & Band I: 415 & Band I: 426 \\
\hline Band II: 260 & Band II: 278 & Band II: 276 & Band II: 274 & Band II: 270 & Band II: 274 \\
\hline Band I: 350 & Band I: 416 & Band I: 398 & Band I: 356, 384 & Band I: 422 & Band I: 418 \\
\hline Band II: 270,291 sh & Band II: 276 & Band II: 276 & Band II: 276 & Band II: 269 & Band II: 270 \\
\hline Band I: 314 & Band I: 368 & Band I: 304,274 & Band I: 302, 274 & Band I: 308 & Band I: 308 \\
\hline Band II: 268 & Band II: 280 & Band II: 230 & Band II: 232 & Band II: 284 & Band II: 288 \\
\hline
\end{tabular}

Table 1: UV-Vis spectrophotometer data of isolated compounds. A: Kaempferol, B: Rutin, C: Luteolin and D: Chrysin-7-glucoside.

The major flavonoid compound that were present in most of polar fractions of both n-butanol and ethanol crude extracts was identified to be chrysin-7-glucoside based on UV-Vis and NMR spectra. Analysis of ${ }^{1} \mathrm{H}$ NMR spectrum showed the presence of one singlet peak at $\delta$ 6.22, which was assigned to $\mathrm{H}_{3}$ of flavone. One doublet with integration of 2 protons appeared at $\delta 6.78$ and assigned to $\mathrm{H} 6$ and $\mathrm{H} 8$. Aromatic ring has symmetrical protons as no substitution is observed. $\mathrm{H} 3^{\prime}$ and $\mathrm{H} 5^{\prime}$ were assigned to $\delta 7.31(2 \mathrm{H}, \mathrm{d})$, while $\mathrm{H} 4^{\prime}$ was assigned to $\delta 7.47(1 \mathrm{H}, \mathrm{t})$ and finally $\mathrm{H} 2^{\prime}$ and $\mathrm{H} 6^{\prime}$ were assigned to $\delta 7.95(2 \mathrm{H}, \mathrm{t})$. Signals of the sugar's protons were found in the region $\delta 2.37$ to 5.51 with the highest $\delta$ (5.51) assigned to $\mathrm{H1}$ ". The ${ }^{13} \mathrm{C}$ NMR spectrum showed signals of flavone aglycone in addition to the signals for the sugar moiety. The signals for $\mathrm{C}-3$ appeared at $\delta 104.9(\mathrm{CH})$ confirming the presence of 2, 3 double bond of the flavone nucleus. Signals for C-6 and $\mathrm{C}-8$ were assigned to $\delta 100(\mathrm{CH})$ and $94.4(\mathrm{CH})$ respectively. For the sugar moiety, signal for C-1" appeared at $\delta 103.1(\mathrm{CH})$, while $\mathrm{CH}_{2}$ signal for C-6" appeared at $\delta$ 63.0. The remaining signals of sugar carbons (C-2" to C-5") were found as CH's at $\delta 70.3,74.3,74.4$ and 76.6. There are weak signals at the region 160-180, corresponding to C-2, C-7 and the carbonyl group at C-4. Together with UV-Vis spectra analysis (Table 1), the identity of the isolated flavonoid compound was confirmed as chrysin-7-glucoside.

\section{Anti-angiogenic activity}

The anti-angiogenic potential of E. angustifolia leaves extracts prepared in four solvents differing in their polarity (ethanol, chloroform, ethyl acetate and water) was investigated. The angiogenic response of rat aortic rings was determined by measuring the length of vessels growing out of the primary ring and compared to $1 \%$ DMSO control. Screening was done first on all extracts using 150, 100 and 50 $\mu \mathrm{g} / \mathrm{mL}$. Based on the screening results, ethanol-, ethyl acetate- and water-extracts were further diluted and tested using concentration as follows: 25, 12.5, 6.25 and $3.125 \mu \mathrm{g} / \mathrm{mL}$. Results obtained from both experiments are shown in Table 2, expressed as percentage of new blood vessels growth inhibition (mean \pm SDEV). The percentage inhibition of vessels outgrowth of $1 \%$ DMSO control showed mean of $0.00 \pm 27.43 \%$. Figure 1 shows the percentage of new blood vessels growth inhibition for the ethanol, ethyl acetate and water extracts. Statistical analysis was done and p-value $<0.05$ was considered significant and NS indicates non-significance. 
Citation: Ishaqat AA, Abu-Dahab R, Hammad HM, Al-Zihlif M, Abaza IF, et al. (2018) Phytochemical Analysis and Evaluation of Anti-angiogenic and Anti-proliferative Activities of the Leaves of Elaeagnus angustifolia L. Grown in Jordan. Nat Prod Chem Res 6: 319. doi: $10.4172 / 2329-6836.1000319$

Page 4 of 6

\begin{tabular}{|l|l|l|l|l|}
\hline Concentration & $\begin{array}{l}\text { Ethanol } \\
\text { extract }\end{array}$ & $\begin{array}{l}\text { Chloroform } \\
\text { extract }\end{array}$ & $\begin{array}{l}\text { Ethyl } \\
\text { acetate } \\
\text { extract }\end{array}$ & $\begin{array}{l}\text { Water } \\
\text { extract }\end{array}$ \\
\hline $150 \mu \mathrm{g} / \mathrm{mL}$ & $100 \pm 0.00$ & $100 \pm 0.00$ & $100 \pm 0.00$ & $100 \pm 0.00$ \\
\hline $100 \mu \mathrm{g} / \mathrm{mL}$ & $100 \pm 0.00$ & $94.36 \pm 7.98$ & $100 \pm 0.00$ & $100 \pm 0.00$ \\
\hline $50 \mu \mathrm{g} / \mathrm{mL}$ & $98.55 \pm 1.45$ & $33.57 \pm 3.33$ & $100 \pm 0.00$ & $100 \pm 0.00$ \\
\hline $25 \mu \mathrm{g} / \mathrm{mL}$ & $98.91 \pm 1.54$ & $\mathrm{NA}^{*}$ & $100 \pm 0.00$ & $96.86 \pm 2.39$ \\
\hline $12.5 \mu \mathrm{g} / \mathrm{mL}$ & $100 \pm 0.00$ & $\mathrm{NA}^{*}$ & $69.48 \pm 43.16$ & $85.20 \pm 13.46$ \\
\hline $6.25 \mu \mathrm{g} / \mathrm{mL}$ & $100 \pm 0.00$ & $\mathrm{NA}^{*}$ & $54.33 \pm 28.84$ & $40.44 \pm 32.59$ \\
\hline $3.125 \mu \mathrm{gg} / \mathrm{mL}$ & $66.54 \pm 24.50$ & $\mathrm{NA}^{*}$ & $35.17 \pm 22.18$ & $14.58 \pm 0.14$ \\
\hline $\mathrm{NA} * \mathrm{not}$ available & & &
\end{tabular}

Table 2: Percentage inhibition of angiogenesis exhibited by four extracts of $E$. angustifolia leaves (mean \pm SDEV).

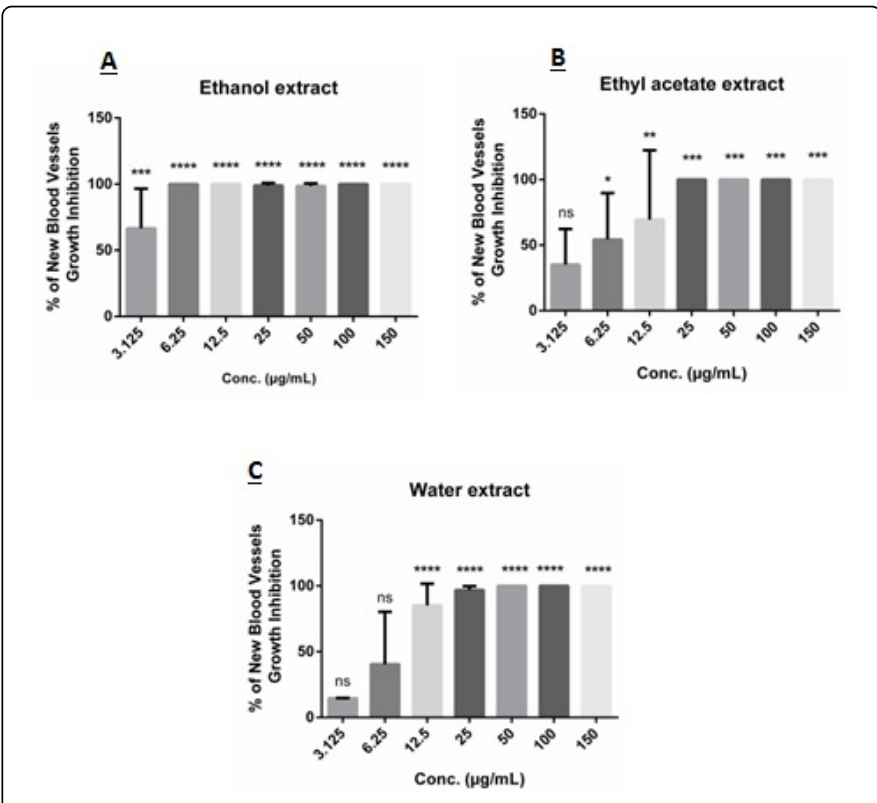

Figure 1: The anti-angiogenic effect determined by \% of new blood vessel growth inhibition from the primary ring. A. ethanol extract B. ethyl acetate extract C. water extract, where ${ }^{*}$ signifies $\mathrm{p}<0.05$, ${ }^{* *}$ signifies $\mathrm{p}<0.01,{ }^{\star * \star}$ signifies $\mathrm{p}<0.001$ and ${ }^{\star * * *}$ signifies $\mathrm{p}<0.0001$.

GraphPad Prism 6 software was used to generate sigmoidal model and calculate $\mathrm{IC}_{50}$ values for the three extracts. Figure 2 shows the sigmoidal model obtained by nonlinear fit. All $\mathrm{R}_{2}$ values were excellent $(>0.98)$ and indicated sufficient fitness of the model. IC $_{50}$ values of ethanol, ethyl acetate and water extracts were found to be $3.039,6.289$ and $7.153 \mu \mathrm{g} / \mathrm{mL}$ respectively.

The angiogenic response of the rat aortic rings to the control and the most potent extract (ethanol) at various concentrations are shown in Figure 3 as images captured of the rings at day 6 of the experiment.

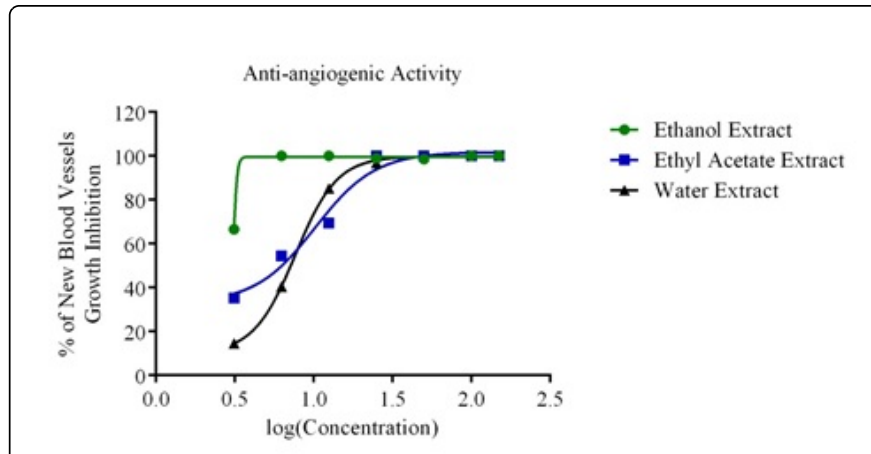

Figure 2: Anti-angiogenic activity of ethanol- $(\bullet)$, ethyl acetate- (•) and water- $(\mathbf{\Delta})$ extracts of $E$. angustifolia leaves.

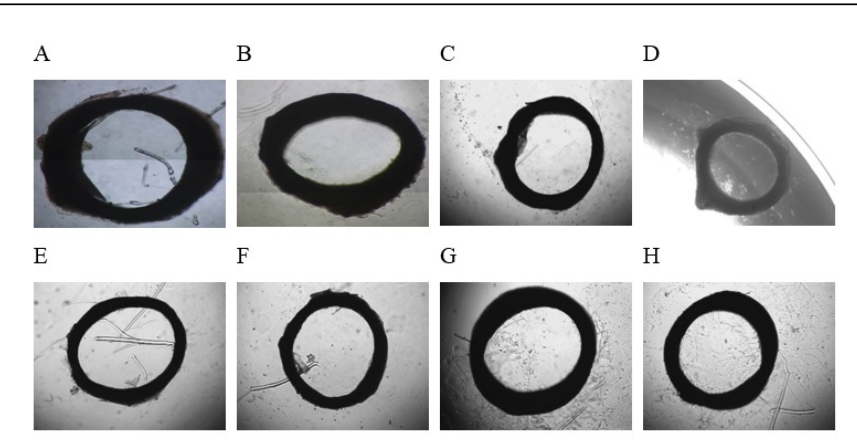

Figure 3: Anti-angiogenic response of rat aortic rings to ethanol extract at concentration of $150 \mu \mathrm{g} / \mathrm{mL}$ (A), $100 \mu \mathrm{g} / \mathrm{mL}$ (B), 50 $\mu \mathrm{g} / \mathrm{mL}$ (C), $25 \mu \mathrm{g} / \mathrm{mL}$ (D), $12.5 \mu \mathrm{g} / \mathrm{mL}$ (E), $6.25 \mu \mathrm{g} / \mathrm{mL}$ (F), 3.125 $\mu \mathrm{g} / \mathrm{mL}(\mathrm{G})$ and control $(\mathrm{H})$.

\section{Anti-proliferative activity}

In the present study, the anti-proliferative properties of four extracts of $E$. angustifolia leaves were evaluated using SRB assay. The assay was conducted on two breast cancer cell lines; MCF-7 and T-47D. The experiment was done in duplicate on two different passages of the cell lines. Nine concentrations were used, each applied in triplicate. The percentage proliferation of each concentration was calculated by dividing the absorbance of the test well on the average of control wells (1\% DMSO). Results expressed as a curve of percent proliferation against logarithm of concentration, using GraphPad Prism 6 software, are shown in Figure 4. 
Citation: Ishaqat AA, Abu-Dahab R, Hammad HM, Al-Zihlif M, Abaza IF, et al. (2018) Phytochemical Analysis and Evaluation of Anti-angiogenic and Anti-proliferative Activities of the Leaves of Elaeagnus angustifolia L. Grown in Jordan. Nat Prod Chem Res 6: 319. doi: $10.4172 / 2329-6836.1000319$

Page 5 of 6

$\underline{A}$

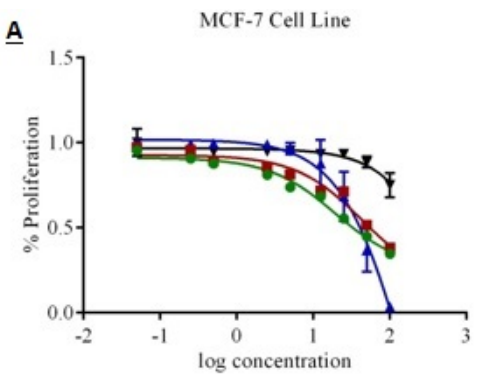

B

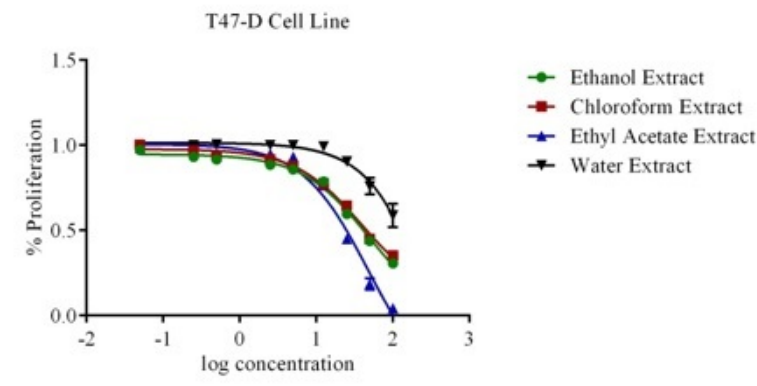

Figure 4: Anti-proliferative activity of ethanol- $(\bullet)$, chloroform- (•), ethyl acetate- $(\boldsymbol{\Delta})$ and water- $(\boldsymbol{\nabla})$ extracts of $E$. angustifolia leaves against MCF-7 (A) and T-47D (B) cell lines.

The $\mathrm{IC}_{50}$ values were calculated and listed in Table 3. Doxorubicin control had $\mathrm{IC}_{50}$ values of $0.2498 \pm 0.0765 \mu \mathrm{M}$ for MCF-7 cell line and $0.1 \pm 0.01 \mu \mathrm{M}$ for $\mathrm{T}-47 \mathrm{D}$ cell line. Ideally, $\mathrm{IC}_{50}$ values should be calculated from perfect sigmoidal curves. Although the curves obtained in this study were not perfect sigmoidal curves, we couldn't increase the concentration of the extracts beyond $100 \mu \mathrm{g} / \mathrm{mL}$ due to the cytotoxic activity of the solvent used. The resulting effects on cell cytotoxicity will be mixed between the solvent and extract chemical constituents. More accurate calculation of $\mathrm{IC}_{50}$ will be studied in more advanced animal studies.

\begin{tabular}{|c|c|c|c|c|}
\hline \multirow{2}{*}{$\begin{array}{l}\text { E. angustifolia } \\
\text { leaves extract }\end{array}$} & \multicolumn{2}{|c|}{$\mathrm{IC}_{50}(\mu \mathrm{g} / \mathrm{mL}) \pm \mathrm{SDEV}$} & \multirow[t]{2}{*}{ p-value } & \multirow{2}{*}{$\begin{array}{l}\text { Significanc } \\
\text { e }\end{array}$} \\
\hline & MCF-7 cell line & T-47D cell line & & \\
\hline Ethanol & $39.03 \pm 0.86$ & $39.26 \pm 0.75$ & 0.8018 & No \\
\hline Chloroform & $60.63 \pm 0.31$ & $44.53 \pm 2.46$ & $<0.0001$ & Yes \\
\hline Ethyl acetate & $38.41 \pm 6.08$ & $23.05 \pm 0.90$ & $<0.0001$ & Yes \\
\hline Water & $188.76 \pm 34.89$ & $270.14 \pm 16.27$ & $<0.0001$ & Yes \\
\hline
\end{tabular}

Table 3: $\mathrm{IC}_{50}$ values of ethanol-, chloroform-, ethyl acetate- and waterextracts of E. angustifolia leaves on MCF-7 and T-47D cell lines (mean \pm SDEV).

According to the NCI guidelines, crude extracts that have $\mathrm{IC}_{50}<100$ $\mu \mathrm{g} / \mathrm{mL}$ in preliminary assay are considered to be active. However, only crude extracts with $\mathrm{IC}_{50}$ value $<30 \mu \mathrm{g} / \mathrm{mL}$ are considered to be cytotoxic $[24,25]$. As a result, activity was demonstrated for ethanol, chloroform and ethyl acetate extracts of E. angustifolia leaves against both MCF-7 and T-47D cell lines. Nevertheless, only ethyl acetate extract was found cytotoxic against T-47D cell line with $\mathrm{IC}_{50}=23.05$ $\mu \mathrm{g} / \mathrm{mL}$, which was significantly different than $\mathrm{IC}_{50}$ values of other extracts against same cell line.

In order to study the selective cytotoxic effect of $E$. angustifolia leaves extracts, a cell proliferation assay against normal fibroblasts cell line was done. Figure 5 exhibits the obtained data. The $\mathrm{IC}_{50}$ values for the extracts against fibroblasts could not be determined by the software, because interpolated values were way outside the output range for the fitted curve, indicating that extracts under study showed very low toxicity against normal fibroblast cells. This indicates a selective activity against cancer cells, which is advantageous in the search for new anticancer compounds. However, further detailed toxicity studies, both in-vitro and in-vivo, are needed to confirm the safety of the extracts and their active constituents.

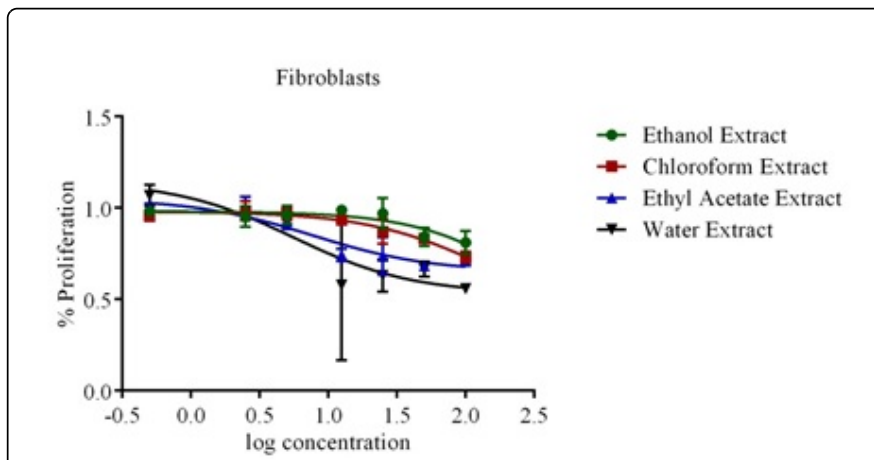

Figure 5: Anti-proliferative activity of ethanol- $(\bullet)$, chloroform- $(\bullet)$, ethyl acetate- $(\boldsymbol{\Delta})$ and water- $(\boldsymbol{\nabla})$ extracts of E. angustifolia leaves against normal fibroblasts cell line.

\section{Conclusion}

The present study reported the chemical analysis of $E$. angustifolia $L$. leaves, grown in Jordan. Chemical classes of secondary metabolites identified were terpenes and flavonoids. Using NMR, $\beta$-sitosterol and chrysin-7-glucoside were identified. Using UV-Vis spectra along with shifting reagents, kaempferol, rutin and luteolin were identified. To the best of our knowledge, these compounds were isolated for the first time from $E$. angustifolia leaves.

Four extracts of $E$. angustifolia leaves, grown locally in Jordan, were obtained using solvents differing in their polarity; ethanol, chloroform, ethyl acetate and water. They were assessed for their anti-angiogenic activity using rat aortic ring assay and anti-proliferative activity against two breast cancer cell lines (MCF-7 and T-47D). Results indicated that ethanol, ethyl acetate and chloroform extracts were active inhibitors of cell proliferation of both MCF-7 and T-47D, while water extract was found to be inactive against both cell lines. Furthermore, ethyl acetate extract was found cytotoxic against T-47D cell line with $\mathrm{IC}_{50}=23.05$ $\mu \mathrm{g} / \mathrm{mL}$. In addition, potent anti-angiogenic activity of ethanol extract $\left(\mathrm{IC}_{50}=3.039 \mu \mathrm{g} / \mathrm{mL}\right)$, ethyl acetate extract $\left(\mathrm{IC}_{50}=6.289 \mu \mathrm{g} / \mathrm{mL}\right)$ and water extract $\left(\mathrm{IC}_{50}=7.153 \mu \mathrm{g} / \mathrm{mL}\right)$ was reported for the first time for $E$. angustifolia leaves. This plant should be further assessed for its antiproliferative activity using additional cancer cell lines. The antiangiogenic activity also needs further evaluation using CAM assay. 
Citation: Ishaqat AA, Abu-Dahab R, Hammad HM, Al-Zihlif M, Abaza IF, et al. (2018) Phytochemical Analysis and Evaluation of Anti-angiogenic and Anti-proliferative Activities of the Leaves of Elaeagnus angustifolia L. Grown in Jordan. Nat Prod Chem Res 6: 319. doi: $10.4172 / 2329-6836.1000319$

Page 6 of 6

\section{Acknowledgments}

This work was supported by a grant from the Deanship of Academic Research, the University of Jordan.

\section{References}

1. Brusic V, Rudy G, Honeyman G, Hammer J, Harrison L (1998) Prediction of MHC class II- binding peptides using an evolutionary algorithm and artificial neural network. Bioinformatics 14: 121-130.

2. Bailey L, Bailey E, Hortorium L, Ithaca N (1976) Hortus Third: A concise dictionary of plants cultivated in the United States and Canada: Macmillan, New York.

3. Mirhydar H (1998) Encyclopedia of plants: indications of plants in the prevention and treatment of diseases: Islamic Farhang, Tehran.

4. Chopra R (1969) Supplement to glossary of Indian medicinal plants.

5. Zargari A (1990) Medical plants: Tehran: Institute of Tehran University Publications and Printing.

6. Saboonchian F, Jamei R, Hosseini Sarghein S (2013) Phenolic and flavonoid content of Elaeagnus angustifolia L. (leaf and flower). Avicenna J Phytomed 4: 231-238.

7. Gürbüz I, Üstün O, Yesilada E, Sezik E, Kutsal O (2003) Anti-ulcerogenic activity of some plants used as folk remedy in Turkey. J Ethnopharmaco 88: 93-97.

8. Hosseinzadeh H, Ramezani M, Namjo N (2003) Muscle relaxant activity of Elaeagnus angustifolia L. fruit seeds in mice. J Ethnopharmaco 84: 275-278.

9. Ahmadiani A, Hosseiny J, Semnanian S, Javan M, Saeedi F, et al. (2000) Antinociceptive and anti-inflammatory effects of Elaeagnus angustifolia fruit extract. J Ethnopharmaco 72: 287-292.

10. Ramezani M, Hosseinzadeh H, Daneshmand N (2001) Antinociceptive effect of Elaeagnus angustifolia fruit seeds in mice. Fitoterapia 72: 255-262.

11. Farahbakhsh S, Arbabian S, Emami F, Rastegar Moghadam B (2011) Inhibition of Cyclooxygenase type 1 and 2 enzyme by aqueous extract of Elaeagnus angustifolia in mice. Basic and Clinic Neurosci 2: 31-37.
12. Alishiri G, Ahmadiani A, Bayat N, Kamalinejhad M, Salim Zadeh A, et al. (2007) Efficacy of Elaeagnus angustifolia extract in treatment of osteoarithritis of knee: a randomized double-blind placebo-controlled trial. Trauma Monthly 12: 49-57.

13. Natanzi M, Pasalar P, Kamalinejad M, Dehpour A, Tavangar S, et al. (2012) Effect of aqueous extract of Elaeagnus angustifolia fruit on experimental cutaneous wound healing in rats. Acta Medica Iranica 50: 589-596.

14. Hekmatian E, Asghari G, Najafi R, Hosein S, Moosavi S (2012) Evaluation of the effect of Elaeagnus angustifolia drug film on gag reflex. J Isfahan Dental School 7: 4.

15. Stewart BW, Wild CP (2014) World Cancer Report 2014: IARC Press, International Agency for Research on Cancer.

16. World Health Organization (2014) Cancer (Fact sheet N297), Geneva.

17. Risau W, Flamme I (1995) Vasculogenesis. Annual Rev Cell Develop Bio 11: 73-91.

18. Folkman J (1971) Tumor angiogenesis: therapeutic implications. New England Journal of Medicine 285: 1182-1186.

19. Ausprunk D, Folkman J (1977) Migration and proliferation of endothelial cells in preformed and newly formed blood vessels during tumor angiogenesis. Microvas Res 14: 53-65.

20. Muthukkaruppan V, Kubai L, Auerbach R (1982) Tumor-induced neovascularization in the mouse eye. J Nat Cancer Ins 69: 699-708.

21. Kumaran G, Clamp A, Jayson G (2008) Angiogenesis as a therapeutic target in cancer. Clinic Med 8: 455-458.

22. Ribatti D, Crivellato E (2012) "Sprouting angiogenesis", a reappraisal. Develop Bio 372: 157-165.

23. Abu-Dahab R, Afifi F (2007) Antiproliferative activity of selected medicinal plants of Jordan against a breast adenocarcinoma cell line (MCF7). Sci Pharma 75: 121-136.

24. Harborne JM, Marby H (1975) The Flavonoids. Academic Press.

25. Suffness M, Pezzuto J (1990) Assays Related to Cancer Drug Discovery. In: Methods in Plant Biochemistry. London: Academic Press, p: 71-133. 